Кірпічніков Ю. А., к.т.н.

Андрощук О. В. ${ }^{1}$;

Петрушен М. В. ${ }^{1}$;

Бичков О. С., к.ф.-м.н., доцент ${ }^{2}$

1 - Центр воєнно-стратегічних досліджень Національного університету оборони України імені Івана Черняховського, Київ;

2 - Київський Національний університет імені Тараса Шевченка

\title{
Шляхи інтеграції даних інформаційних систем управління оборонними ресурсами
}

Резюме. Статтю присвячено проблемі визначення можливих шляхів інтеграції даних, що виникає при реалізації проектів 3 розроблення і створення (модернізації) інформаційних систем управління оборонними ресурсами. Унікальність проектів, їх обмеження по вартості й часу призвело до відсутності єдиних підходів до інтеграції даних. Проекти реалізуються в рамках створення єдиної системи управління оборонними ресурсами, що потребує організації обміну даними як між новими, так і 3 існуючими (успадкованими) системам для підвищення ефективності оборонного планування та управління оборонними ресурсами.

Ключові слова: інформаційна інфраструктура, методи інтеграції, інтеграція даних, інтеграційна шина, сервіс-орієнтовна архітектура.

Постановка проблеми. Створення ефективної системи управління Збройними Силами (3С) України, як основи системи управління обороною держави, є одним із пріоритетних завдань оборонної реформи держави. Стратегічний оборонний бюлетень України [1], у концептуальному вигляді, визначив головні напрями проведення оборонної реформи. Насамперед, це впровадження ефективного оборонного планування та управління оборонними ресурсами 3 використанням сучасних євроатлантичних підходів. Проблемним питанням виконання цього завдання $\epsilon$ той факт, що існуюча система управління ЗС України здебільшого не автоматизована.

Одним iз пріоритетних напрямів, направлених на підвищення ефективності оборонного планування та управління оборонними ресурсами є виконання завдання 1.4.8 "Матриці досягнення стратегічних цілей i виконання основних завдань оборонної реформи" щодо створення єдиної інформаційної системи управління оборонними ресурсами (Defense Resources Management Information System - DRMIS).

Нагальною проблемою, на вирішення якої спрямовано створення DRMIS, $\epsilon$ необхідність забезпечення органів військового управління інформаційно-аналітичною складовою (інструментарієм) для підтримки прийняття рішень у сфері управління оборонними ресурсами за напрямами управління: особовим складом, організаційною структурою, оборонним плануванням, матеріально-технічним забезпеченням, медичним забезпеченням, закупівлями, майном, фінансами та бюджетом, адміністративною діяльністю.

Ступінь розробленості проблеми. На сьогодні за кожним 3 напрямів управління оборонними ресурсами створені окремі інформаційні системи, але вони є різнорідними за часом створення, ступенем завершеності, використаними технологіями, обсягом охоплення процесів, обсягом розгортання та наповнення даними.

Стан інформаційної інфраструктури та забезпечення інформаційних потреб керівного складу ЗС України не відповідає потребам сучасності. Інтеграція інформаційних систем управління оборонними ресурсами за окремими напрямами відсутня або здійснюється фрагментарно, що призводить до дублювання та недостатньої достовірності та повноти інформації щодо комплексного управління оборонними ресурсами в цілому.

Таким чином, незважаючи на впроваджені програмно-технічні рішення, наявні у ЗС України окремі інформаційні системи не забезпечують повною мірою підтримку процесів оборонного планування та управління оборонними ресурсами.

Метою статті є визначення шляхів інтеграції даних інформаційних систем управління оборонними ресурсами для підвищення ефективності оборонного 
планування та управління оборонними ресурсами.

\section{Виклад}

Недостатня

планування, основного

ефективність

управління матеріалу. оборонного оборонними ресурсами та незадовільний стан інформаційної інфраструктури обумовлено такими причинами:

відсутність єдиних методологічних, технічних та організаційних принципів i підходів до створення інформаційних систем та впровадження інформаційних технологій; організаційна розпорошеність та функціональна розрізненість існуючих інформаційних систем;

відсутність єдиної платформи 3 централізованими сервісами доступу, збереження, обробки і обміну даними;

відсутність стандартів обміну даними між інформаційними системами для забезпечення (інтероперабельності); недостатня взаємосумісності

розгалуженість інформаційно-телекомунікаційних мереж та швидких каналів передачі даних; недостатня розробленість питань захисту інформації (інформаційних ресурсів) та висока вартість проведення заходів зі створення комплексних систем захисту інформації;

відсутність єдиної технічної підтримки інформаційних систем, навчання та підтримки користувачів.

Одним зі шляхів розв'язання проблеми є вдосконалення функціональної взаємодії існуючих та перспективних інформаційних систем управління оборонними ресурсами на основі методів інтеграції даних [2]. Інтеграція інформаційних системи управління оборонними ресурсами в єдину систему DRMIS дасть змогу сформувати єдиний інформаційний простір [3], у якому в структурованому вигляді консолідується інформація, забезпечується оперативний доступ до цієї інформації для аналізу i прийняття рішень.

Завдання інтеграції даних та створення DRMIS виникає у зв'язку з тим, що, по-перше, обсяг даних швидко збільшується, особливо за рахунок розвитку нових інформаційних систем, по-друге, інформаційні системи створюються різними розробниками, які використовують різні програмні платформи та системи управління базами даних. Інтеграція даних розуміється як забезпечення єдиного уніфікованого інтерфейсу для доступу до деякої сукупності неоднорідних, незалежних джерел даних. Таким чином, інформаційні ресурси всієї сукупності інтегрованих джерел представляються як єдине джерело. Система, що забезпечує такі можливості, називається системою інтеграції даних [4].

За своєю архітектурою системи інтеграції даних поділяють на основі методів інтеграції даних: консолідація, федералізація, поширення, сервісний підхід [5].

При використанні методу консолідащіï, дані збираються з декількох первинних систем і інтегруються в одне загальне сховище. Це однобічно направлений процес, що виконується 3 деяким інтервалом часу та призводить до певної затримки оновлення даних.

При використанні методу федералізаयіï даних утворюється єдиний віртуальний інформаційний простір, в якому дані зберігаються в різних джерелах. Отримання даних виконується шляхом запиту, який поділяється на множину запитів, що адресовані до потрібних локальних джерел. В іншому цей процес схожий з консолідацією.

Метод поширення даних полягає у перенесенні даних 3 однієї системи в іншу в оперативному режимі, в залежності від певних подій. Оновлені дані в первинній системі можуть передаватися в кінцеву систему синхронно або асинхронно. Незалежно від типу синхронізації, метод поширення гарантує доставку даних в систему призначення. Як правило, синхронне поширення підтримує двосторонній обмін даними між первинними $\mathrm{i}$ кінцевими системами.

Сервісний niдxid дає змогу об'єднати інформацію 3 декількох джерел таким чином, щоб надати іiі у вигляді сервісу. Сервіси - це окремі програмні компоненти, що надають певну функціональність за допомогою серії запитів на необхідну інформацію та інших сервісів. Як правило, сервіси будуються на обмеженій кількості запитів на необхідну згідно його функцій інформацію.

Залежно від обраної архітектури, для створення системи інтеграції даних інформаційних систем управління оборонними ресурсами можна застосувати кілька підходів [6]. Серед них можна виділити три основні nidxoдu до створення інтеграційної системи на основі:

1) використання монолітної системи класу ERP;

2) методів консолідації, федералізації та поширення даних;

3) сервіс-орієнтованої архітектури.

ERP-система може забезпечити підтримку управління фінансовими, 
матеріальними, кадровими ресурсами на всіх рівнях управління, забезпечити актуальною інформацією, необхідною для прийняття оперативних і стратегічних рішень. Ключовою особливістю сучасних ERP-систем $\epsilon$ використання методик та інтегрованих аналітичних засобів стратегічного управління, що забезпечують управління як на рівні структурних підрозділів, так i поширення процесів управління на стратегічному рівні.

Другий підхід полягає в консолідації даних існуючих інформаційних систем 3 використанням єдиної концепції мережевої взаємодії і управління доступом до ресурсів. Його застосування забезпечить перенесення в більш сучасне інформаційне середовище функцій успадкованих інформаційних систем 3 подальшим використанням наявних даних, а також дасть змогу впроваджувати нові інформаційні системи на базі єдиної технології. При застосуванні цього підходу необхідно вирішити: який інструментальний програмний засіб краще вибрати, як надалі будуть розроблятися нові модулі системи, яких стандартів дотримуватися в проектуванні та розробленні.

Суть третього підходу полягає у застосуванні сервіс-орієнтованої архітектури на основі технології відкритих систем , що забезпечує:

уніфікований обмін даними між різними інформаційними системами;

просте налаштування взаємодії 3 успадкованими системами;

гнучкість інформаційної інфраструктури (швидке реагування на зміни);

зниження витрат на інтеграцію, супроводження та масштабування.

Основою, що забезпечує реалізацію цього підходу, служить сукупність стандартів, за допомогою яких уніфікується взаємодія всіх компонентів інформаційного середовища: засобів введення-виведення, інтерфейсів та протоколів передачі даних у мережах тощо.

Зважаючи на наведені підходи, можливими варіантами інтеграції даних інформаційних систем управління оборонними ресурсами та створення DRMIS $є$ такі:

Перший варіант - закупівля готового програмного забезпечення класу ERP управління ресурсами підприємства закордонного або вітчизняного розробника (що використовується в країнах-партнерах НАТО або в інших міністерствах України) та створення DRMIS на основі єдиної програмної платформи.
Перевагами цього підходу є: готові перевірені рішення, висока якість продукту; короткі терміни впровадження; єдина технологія, єдина платформа, єдиний розробник; широкий вибір фахівців 3 впровадження i підтримки індустріальних програмних рішень на ринку праці; стандартизовані процедури навчання користувачів та технічної підтримки на високому рівні від розробника зі світовим досвідом; подальша підготовка користувачів власними навченими фахівцями.

У якості недоліків необхідно відмітити: висока вартість програмного продукту, доналаштувань та технічної підтримки; складність розроблення та впровадження нової системи; повна залежність від постачальника.

Реалізація першого варіанта сприяє своєчасному виконанню завдань щодо створення DRMIS, але може вимагати значних фінансових ресурсів на придбання ліцензій на право використання програмного рішення, його впровадження та подальшу підтримку.

Другий варіант - розроблення нового програмного забезпечення, окремо за кожним функціональним напрямом управління оборонними ресурсами, та подальше створення DRMIS шляхом інтеграції наявних та нових створюваних систем за допомогою інтеграційної шини та визначених протоколів обміну даними.

Основними перевагами $є$ : нижча, у порівнянні 3 першим варіантом, вартість реалізації від вітчизняного розробника (залежно від ліцензійної політики); подальше використання існуючих інформаційних систем, на розроблення та впровадження яких витрачено значний фінансовий ресурс; можлива диверсифікація розробників.

Можливими недоліками є: нижча, ніж у індустріального програмного забезпечення, якість; довші терміни розроблення i впровадження; необхідність підготовки користувачів по кожній системі окремо; технічна підтримка по кожній системі окремо; відсутність підготовки користувачів та технічної підтримки успадкованих систем; залежність від розробників; ризики припинення існування невеликих розробників.

Реалізація другого варіанта може ускладнити процес створення DRMIS на основі єдиної ідеології та проектних (технологічних) рішень, має більш високі ризики виконання.

Tpemiй варіанm - комбінований підхід до створення DRMIS на основі використання індустріальної інтеграційної платформи, у якій реалізовані принципи сервіс-орієнтованої 
архітектури та технології відкритих систем, для створення нових (за неавтоматизованими напрямами управління оборонними ресурсами) та забезпечення сумісності (інтероперабельності) 3 існуючими інформаційними системами.

Третій варіант поєднує переваги першого та другого варіантів, нівелює більшість їх недоліків, зокрема, знижує ризики неуспіху реалізації системи згідно 3 другим варіантом.

Реалізація третього варіанта дасть змогу виконати завдання зі створення DRMIS на основі єдиної ідеології та проектних (технологічних) рішень з меншими витратами фінансових, матеріально-технічних та трудових ресурсів.

Висновки. На сучасному етапі створення системи управління 3С України визначення раціонального підходу до інтеграції даних існуючих та перспективних інформаційних систем управління оборонними ресурсами $\epsilon$ актуальним завданням. Представлені у статті підходи можуть служити основою для здійснення такої інтеграції у єдину систему управління оборонними ресурсами DRMIS. Використання інтегрованої системи, а не сукупності окремих систем дасть змогу значно підвищити ефективність та знизити витрати, що пов'язані
3 інформаційним забезпеченням процесів оборонного планування та управління оборонними ресурсами.

Вибір та обгрунтування одного 3 шляхів інтеграції даних інформаційних систем управління оборонними ресурсами є актуальною темою подальших досліджень.

\section{СПИСОК ВИКОРИСТАНОЇ ЛІТЕРАТУРИ}

1. Про рішення Ради національної безпеки і оборони України від 20 травня 2016 року "Про Стратегічний оборонний бюлетень України” [Електронний ресурс]: указ [видано Президентом України 06 червня 2016 р. №240/2016]. - - Режим доступу: http://www.president.gov.ua/ documents/2402016-20137.

2. Кірпічніков Ю. А. Аналіз поняття інтеграційної платформи та методів інтеграції даних інформаційних систем управління / Ю. А. Кірпічніков, М. В. Петрушен, О. В. Андрощук. // Збірник наукових праць ЦВСД НУОУ ім. І.Черняховського, стаття. 2017. - №2(60).

3. Сдиний інформаційний простір // Матеріал 3 Вікіпедії - вільної енциклопедії [Електронний pecypc].- Режим доступу: https://uk.wikipedia.org/wiki/ Єдиний_інформаційний_простір.

4. Когаловский M. P. Перспективные технологии информационных систем / Когаловский М. Р.- М: ИТЭкономика, 2003. 288 с.

5. В. Боркус. Методы и инструменты интеграции корпоративных приложений. М.: RC Group, 2005. 215 c.

6. Г. Хоп, . Вульф. Шаблоны интеграции корпоративных приложений. Издательство: Вильямс, 2007. $-672 \mathrm{c}$.

Стаття надійшла до редакції 09.11.17

Кирпичников Ю. А., к.Т.н. ; Андрощук О. В. ${ }^{1}$;

Петрушен Н. В. ${ }^{1}$; Бычков А. С., к.ф.-м.н., доцент ${ }^{2}$

1 - Центр военно-стратегических исследований Национального университета обороны Украины имени Ивана Черняховского, Киев;

2 - Киевский Национальный университет имени Тараса Шевченко

\section{Пути интеграции данных информационных систем управления оборонными ресурсами}

Резюме. Статья посвящена проблеме определения возможных путей интеграции данных, которая возникает при реализации проектов по разработке и созданию (модернизации) информационных систем управления оборонными ресурсами. Проекты реализуются в рамках создания единой системы управления оборонными ресурсами, что требует организации обмена данными, как между новыми, так и с существующими (унаследованными) системами, для повышения эффективности оборонного планирования и управления оборонными ресурсами.

Ключевые слова: информационная инфраструктура, методы интеграции, интеграция данных, интеграционная шина, сервис-ориентированная архитектура.

\section{Y. Kirpichnikov, $\mathrm{PhD}^{1}$; O. Androshchuk ${ }^{1}$;}

N. Petrushen ${ }^{1}$; A. Bychkov, PhD, assistant professor ${ }^{2}$

${ }^{1}$ - Center for Military and Strategic Studies of the National Defence University of Ukraine named after Ivan Cherniakhovsky, Kyiv;

2 - Kyiv National University named after Taras Shevchenko

\section{Ways of data integration of defense resource management information systems}

Resume. The article is devoted to the problem of determining possible ways of data integration, which arises during the implementation of projects for the development and creation (modernization) of information systems for the management of defense resources. Projects are implemented as part of the creation of a unified defense resource management system, which requires the organization of data exchange, both between new and existing (legacy) systems, to improve the effectiveness of defense planning and defense resource management.

Keywords: information infrastructure, integration methods, data integration, integration bus, service-oriented architecture. 